\title{
Predicting Destination Image in Creative Tourism: A Comparative between Tourists and Residents
}

\author{
David Dean $^{\mathrm{a}}$, Dwi Suhartanto ${ }^{\mathrm{b}^{*}}$, and Lusianus Kusdibyo ${ }^{\mathrm{c}}$

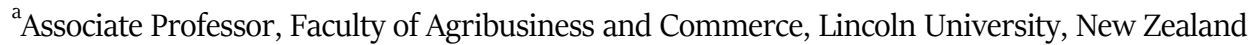 \\ ${ }^{\mathrm{b}, \mathrm{c}}$ Associate Professor, Department of Business Adminstration, Politeknik Negeri Bandung, Indonesia
}

Received 12 September 2018; accepted 20 December 2018

\begin{abstract}
This study's objective is to examine tourist and resident experiences of creative tourist attractions through the development of an experience quality- destination model and assess the interrelationships among model factors: experience quality, perceived value, satisfaction, and destination image. The research was conducted across several creative tourism attractions in Bandung, Indonesia including cultural/traditional dancing, crafting, painting and games. Self-administered questionnaires were distributed to the visitors after they enjoyed the experience. Of the 421 questionnaires collected, 400

were useable for further analysis. The hypotheses are examined by using Partial Least Square (PLS). The proposed experience quality-destination model is a good fit for both the tourist and resident samples. For the tourist sample, all the direct effects among variables in the model are significant except for perceived value's effect on destination image. For the resident sample, experience quality directly influences perceived value, and perceived value directly affects both satisfaction and destination image. The total effect of experience quality on destination image is significant for both samples.
\end{abstract}

\section{KEYWORDS}

Creative attraction Experience quality Perceived value Satisfaction Destination image

\section{INTRODUCTION}

Creative tourism is a promising sector and is increasingly popular in the global tourism market (Hung, Lee, \& Huang, 2016). This sector has a growing positive influence on the development of social, economic, and cultural environments of a community. The growth of creative tourism promotes the development of a destination economy, impacts positively on the destination attractiveness, and contributes to a positive experience when tourists visit the destination (All, Ryu, \& Hussain, 2016; Chang, Backman, \& Huang, 2014). Therefore, creative tourism attractions have become important elements in establishing a destination's attractiveness (Hung et al., 2016). Accordingly, many regions put their efforts towards developing creative attractions to satisfy both tourists and residents' needs. As these attractions multiply, intense competition has grown between creative tourism destinations. In this competitive and challenging environment, an important strategy for destinations is to develop a unique and favorable image (Loi, So, Lo, \& Fong, 2017; Whang, Yong, \& Ko, 2016).

\footnotetext{
*Corresponding Author: dwi.suhartanto@polban.ac.id; doi: 10.35313/ijabr.v1io1.36
}

(C) 2019 Politeknik Negeri Bandung 
Literature in tourism shows that a crucial element in developing a positive destination image is by providing high quality of tourist attractions (Stylidis, Shani, \& Belhassen, 2017). For many years, research has focused on evaluating service quality of the attractions as the main determinant of customer' post purchase behavior. However, although service quality can distinguish a business's services from its competitors, this advantage is eroded as competitors move to reduce differences in service quality. When service quality is perceived as the same, customers look for more than just quality of service (García-Fernández et al., 2018; Meyer \& Schwager, 2007). Recent studies in the tourism industry have uncovered a trend showing that customers are increasingly looking for experiences where they can be actively involved in co-creating value (Dodds \& Jolliffe, 2016; Hung et al., 2016). Considering the importance of the service experience in influencing customer behavior, scholars (Klaus, 2013; McLean \& Wilson, 2016) suggest that researchers should further explore the outcomes of all customer experience drivers. Additionally, past studies have indicated the importance of customer experience on destination image (Kim, Hallab, \& Kim, 2012; Loi et al., 2017). Therefore creative tourist attractions, which are designed around the value co-creation experience, are an ideal setting to examine how experience quality impacts destination image.

Another issue with both experience quality and destination image studies is that too many of them have examined the issue from the tourist's perspective related to a specific attraction and have ignored other aspects of the destination. In fact, a tourist can spend more of their time in a destination but not at a particular attraction, and the way they are treated by the people they interact with can significantly influence the destination's positive or negative atmosphere (Agapito, Mendes, \& Valle, 2010; Stylidis et al., 2017). So, the destination image can be positively or negatively influenced by people that live and/or work in the destination even though these people have no formal connection to tourism.

Because the destination residents and service providers remain at the destination while the tourists come and go, the residents can influence the atmosphere but like the tourists, they are also influenced by it. If the destination has a positive atmosphere for residents, it can be a pleasant place to live and work. Conversely, if it has a negative atmosphere, residents may not feel at home staying at the destination. Studies in tourism have identified such differences between tourists and residents both in attitudes and in behaviors (Agapito et al., 2010; Lloyd, Yip, \& Luk, 2011). Thus, scholars (Agapito et al., 2010; Stylidis et al., 2017) suggest that the assessment of destination image should also take into account the attitudes and behaviors of other stakeholders, not only tourists. In creative tourism, the service providers that co-create value are stakeholders and for activities celebrating local culture or traditions, the residents in the destination also can be key stakeholders because of their strong attachment to and identification with the destination. Thus, creative tourism attractions are a particularly relevant context to understand how tourist experiences as well as resident experiences shape and maintain a destination's image.

Driven by these research gaps, this study explores the association between experience quality and destination image from tourists and residents perspective, in the context of creative tourism attractions. Specifically, this study's purpose is to (1) scrutinize the direct consequence of experience quality on destination image and its indirect effect through customer perceived value and satisfaction; and (2) compare the association between experience quality and destination image of creative tourism across tourists and residents. 


\section{MODEL AND RESEARCH HYPOTHESES}

\section{Development of the Research Model}

This study aims to examine the consequences of experience quality to destination image.

Based on the literature discussed in the following sub-sections, the research model is illustrated in Figure 1.

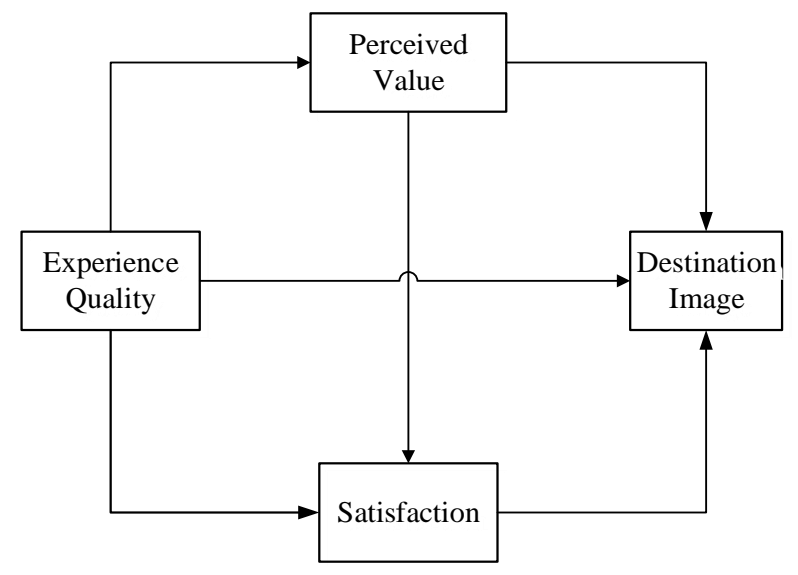

Figure 1. Proposed model

\section{Destination Image in Creative Tourism}

Destination image is a complex concept and its definition varies across scholars. Despite these variations, it is destination image is generally construed as a summation of impressions, beliefs, and ideas a person has regarding a destination (Stylidis et al., 2017). This explanation implies that destination image is a person's overall belief and impression about the features and values derived from a destination. The beliefs and impressions are developed from the information a person obtain from many sources of marketing communication and from the direct interaction with the destination (Chen \& Tsai, 2007). Over time, the information and experience gathered result in a psychological depiction about the destination attributes and destination benefits. Among the image determinants, the experience of visiting the destination are the most significant determinants of destination image (Suhartanto, 2017).

The destination image definition indicates the complexity of the construct, resulting in various approaches used in studying the destination image. The first approach suggests that destination image includes three dimensions containing cognitive, affective, and conative aspects. Based on this contention, Agapito et al. (2013) suggest that destination image encompasses what a person understand and thinks about something (cognitive element), how a person senses it (affective component), and how a person behaves using the information about it (conative element). The component of cognitive image denotes one's comprehension and belief about the attributes of a destination, which concurrently developmental depiction of the destination. The cognitive image contains knowledge and belief about a destination, primarily concentrating on tangible attributes of the destination (Lin, Morais, Kerstetter, \& Hou, 2007). Other scholars argue that the cognitive image consists of a set of features corresponding to the resources of the destination (Zhang, Fu, Cai, \& Lu, 
2014). Those attributes, in the tourism destination context, cover the tourism attraction provider's product, process, service, and promotion as well as the tourism destination environment. All of these factors can induce a customer (both tourist and resident) to enjoy the tourism attraction in a destination.

The affective component of image signifies one's emotional responses toward the destination (Agapito et al., 2013). Affective image occurs in the evaluation and selection of the destination. In various industry contexts including tourism, the component of cognitive and affective is often assessed independently (Stylidis et al., 2017). However, Yuksel, et al. (2010) report that in assessing the destination image, the cognitive and affective component should be integrated. The affective image is the stage of response to a destination and this response directs subsequent behavior towards the destination. Rollero and De Piccoli (2010), in their environmental psychology context study, confirms a positive association between the level of affection on cognitive evaluations of a destination's attributes. However, the majority of studies suggest that the evaluation of the affective component is a consequence of the comprehension of the destination (cognitive component) (Stylidis et al., 2017; Zhang et al., 2014).

There are mixed results in the literature examining the dimensionality of destination image. Some empirical studies have investigated and supported the existence of three elements of destination image: cognitive, affective, and conative (Agapito et al., 2013; Yuksel et al., 2010). Other scholars have found two destination image dimensions; cognitive and affective (Stylidis et al., 2017; Zhang et al., 2014). For the studies finding two dimensions, destination image is shaped from a person's views and affect the destination. In essence, the cognitive component is the determinant of affective component. This two dimension approach is consistent with the Theory of Reasoned Action and is commonly used (Li, Cai, Lehto, \& Huang, 2010). A final group of researchers (Qu, Kim, \& Im, 2011; Zhang et al., 2014) suggest that destination image has only one dimension when researching tourism destinations. Whang et al. (2016) suggest destination image as an all-inclusive opinion of a particular destination which results from the evaluation of affective, cognitive, and conative aspects of destination image. Recent studies in tourism (Choi, Tkachenko, Sil, \& Cohen, 2011) and in shopping tourism report a robust measurement of destination image as a single dimension. Thus, this study applies this single approach to measure destination image in creative tourism.

\section{Experience Quality in Creative Attractions}

Research examining service experience suggests that scholars have different conceptualizations of experience quality. For instance, Chen and Chen (2010) advocate that experience quality is a tourist's social and psychological response to an attraction they experienced during a visit. This description implies that experience quality differs conceptually from service quality. This view is consistent with Deshwal (2016), who contends that the scope of customer' experience quality is bigger when compared to service quality because experience quality includes emotions and feelings while service quality doesn't. Dodds and Jolliffe (2016) maintain that, as an element of service experience, experience quality is characterized as feelings of fun and fantasy. They contend that consumer experience occurs during attraction consumption as well before; as early as when the customer first opens communication with the service provider.

The dimensions of experience quality are debated in the literature. An early study by Pine and Gilmore (1998) notes that entertainment, aesthetic, educational, and escapism are the dimension of experience quality. Hung et al. (2016) maintain that the attraction should provide a sense of escaping 
and enable visitors to participate in the attraction to create their personal experience. In the package tour service, $\mathrm{Xu}$ and Chan (2010) support the presence of tourist experience quality consisting of hedonics, escape, recognition, involvement, relaxation, and peace of mind. A further validation of these dimensions by Ali et al. (2016) in contemporary creative attractions, reveals that tourists depend on involvement and learning in the attraction and then, apply the acquired knowledge and skills from the attraction. This conceptualization is comparable with Pine and Gilmore (1998)' concept of educational experience. To conclude, most of the studies identify that escapism, peace of mind, involvement, learning, recognition are pivotal elements of experience quality.

Tourism service consumption, as in creative attraction consumption, is a complex system which is comprised of many factors. According to Woodside and Dubelaar (2002), visitor opinions, choices, and behavior related to traveling are directly or indirectly related to each other. In a similar tone, Spillover Theory suggests that experience with a life experience may modify another aspect of life experience (Sirgy, Efraty, Siegel, \& Lee, 2001). Using this theory and the Woodside and Dubelaar (2002) contention, the authors argue that customers' experience with a creative tourism attraction can affect their perception of the tourism destination where the attraction is located. The basis for the connection between these concepts is that a creative attraction is an important element of the destination offering. Thus, it is anticipated that customers experience with the attraction will impact their overall perception toward the destination. Past study carried out by Beerli and Martín (2004) report that tourist vacation experience impacts the cognitive aspect of destination image. Kim et al. (2012)' study among US student travelers concludes that travel experience strengthens the image of a destination. Thus, in the creative tourism, it is expected that customers (both tourists and residents)' experience with the creative attraction will impact their image of the destination.

H1: Experience quality has a direct and positive effect on destination image

\section{The Role of Perceived Value}

The 'perceived value' term is associated with a relative comparison between the sacrifices and benefits with the product or services consumed. Perceived value is a multifaceted concept, consisting of functional, social, and sense of well-being value (Chen \& Chen, 2010; García-Fernández et al., 2018). The conceptual basis of perceived value is equity theory which postulates the proportion between the provider's outcome and the consumer's input (García-Fernández et al., 2018). Customers feel treated fairly if they feel that the proportion between their sacrifices and experiences obtained is equivalent. The association between the customers and the service providers is stronger if the customers perceive that they gain higher benefits for their sacrifices in terms of both monetary and non-monetary, which subsequently affect their future behavior. Past research provides evidence that customer service experience influences perceived value (García-Fernández et al., 2018). Further, past studies also report the influence of perceived value on destination image (Chen \& Tsai, 2007). This discussion suggests that the link between experience quality and destination image is moderated by perceived value.

H2: Experience quality has a direct and positive effect on perceived value

H3: Perceived value has a direct and positive effect on destination image 


\section{Satisfaction with Creative Attraction}

Customer satisfaction of a creative attraction is the customer's perceived difference between the attraction performance and prior expectation (Ali et al., 2016; Suhartanto \& Noor, 2012). Chen and Chen (2010) maintain that satisfaction is an amalgam of tourists' expectations prior to travelling and their experience after travelling. Tourists are satisfied if their expectations are fulfilled. In contrast, tourists will be dissatisfied if they perceived the experience was less than what they expected resulting a feeling of unhappiness. Related to experience quality, past studies note that experience quality directly influences tourist satisfaction with a tourism attraction. For example, Chang et al. (2014)' study concludes that if a customer experience is favorable, he or she tends to be satisfied with the attraction. Some current studies (Ali et al., 2016; Kim \& Choi, 2016) have also found support for the association between tourist experience and positive behavior towards an attraction e.g. visitor satisfaction and revisit intention. Other research (Ali et al., 2016) has found links between tourist satisfaction and destination image. These studies show that tourists who are satisfied with the attraction have a favorable image towards the destination. Due to the influence of satisfaction on destination image, having satisfied tourists is pivotal to the success of tourism attractions (Dodds \& Jolliffe, 2016). This discussion suggests that the link between experience quality and destination image is moderated by customer satisfaction.

H4: Perceived value has a direct and positive effect on satisfaction

H5: Experience quality has a direct and positive effect on perceived value

H6: Satisfaction has a direct and positive effect on destination image

\section{RESEARCH METHOD}

The constructs in the experience quality - destination image model, including the elements of destination image and its determinants, i.e. experience quality, customer value, and satisfaction have been developed and empirically assessed by a number of researchers and studies. Therefore, the measurement of the constructs applied in this study draws from the existing literature. Table 1 details the constructs that this research proposes to measure and the supporting literature sources.

The data gathering tool was a questionnaire. The questionnaire consisted of seven items that reflected the experience quality dimensions of escape, recognition, involvement, peace of mind, and learning. These items, as well as perceived value, and destination image were assessed by a 5-point Likert scales, with 1 strongly disagree, and 5 strongly agree. The customer satisfaction construct was assessed by a 5-point semantic differential scale, from "dissatisfied" to "satisfied" and from "terrible" to "pleased".

Three tourism academics inspected the questionnaire prior to pretesting and data collection for clarity and the appropriateness of the instructions and questions. The data collection was conducted at several creative tourism attractions in Bandung region, Indonesia during February and March 2018. The attractions were traditional dancing, batik painting, crafting puppets, taking part in traditional music performance, and engaging in traditional games. As the sampling frame in this study could not be identified, this study used purposive sampling. Data was collected using a selfadministered questionnaire, given to the visitors at the end of creative attraction. Of the 421 visitors 


\section{SUHARTANTO, ET AL.}

who were willing to participate, 400 returned a completed and useable questionnaire which was a sufficient sample size to employ structural equation modeling (Hair, Hult, Ringle, \& Sarstedt, 2017).

Following scholars (Hair et al., 2017) recommendation, the confirmatory factor analysis was utilized to test the construct validity and reliability while partial least square was employed to assess the proposed model and hypotheses. The partial least squares was employed as it is a commonly used method for assessing path coefficients in structural models. The utilization of this method was also chosen due to its ability to analyze non-normally distributed data (Henseler, Ringle, \& Sarstedt, 2015).

Table 1. Scale measurements and their sources

\begin{tabular}{|c|c|}
\hline Construct & Sources \\
\hline \multicolumn{2}{|l|}{ 1. Experience quality } \\
\hline \multicolumn{2}{|l|}{ Escape } \\
\hline Recognition & (Chang et al., 2014; Chen \& Chen, 2010; Deshwal, \\
\hline Involvement & 2016; Hung et al., 2016; Pine \& Gilmore, 1998) \\
\hline \multicolumn{2}{|l|}{ Peace of mind } \\
\hline \multicolumn{2}{|l|}{ Learning } \\
\hline 2. Customer Satisfaction & (Ali et al., 2016; Chen \& Chen, 2010) \\
\hline 3. Perceived Value & (Chang et al., 2014; García-Fernández et al., 2018) \\
\hline 4. Destination image & $\begin{array}{l}\text { (Stylos, Vassiliadis, Bellou, \& Andronikidis, 2016; } \\
\text { Zhang et al., 2014) }\end{array}$ \\
\hline
\end{tabular}

\section{RESULTS}

Of 400 usable data, domestic tourists represented the majority (250), with 13 foreign tourists, and 150 residents. The demographic respondent' characteristics is shown in Table 2.

Table 2. Characteristics of the respondent

\begin{tabular}{clrr}
\hline Variable & Description & Tourist & Residence \\
\hline \multirow{4}{*}{ Age } & $<$ 17 years & 41 & 32 \\
& 17-37 years & 149 & 101 \\
& $>$ 37 years & 60 & 17 \\
& Male & 111 & 56 \\
Occupation & Female & 139 & 94 \\
& Student & 232 & 91 \\
& Entrepreneur & 54 & 31 \\
& Employee & 48 & 23 \\
& Others & 16 & 5 \\
Number of visit & 1 (first) & 175 & 66 \\
& $>1$ & 75 & 84 \\
& Alone & 9 & 11 \\
& Friends & 77 & 89 \\
Visited with & Entourage & 149 & 42 \\
& Others & 15 & 8 \\
\hline
\end{tabular}




\section{Measurement Model}

To assess the proposed model, a two-stage examination approach was applied. The first stage examined the model of measurement by evaluating the average variance extracted (AVE), Cronbach's Alpha for composite reliability (CR), and outer loading to judge both reliability and validity of the constructs. The results (Table 3) show that the AVE values are greater than $0.5, \mathrm{CR}$ and Alpha values are more than 0.7 (except Cronbach' Alpha value for satisfaction), and factor loading values exceed 0.6 , indicating that the constructs are valid and reliable.

Henseler and colleagues (2015) recommend the Heterotrait-Monotrait (HTMT) ratio as a method to examine construct discriminant validity and they suggest that a ratio value of less than 0.9 indicates that a construct is valid. The HTMT ratios for all of the constructs had values of less than 0.9 , satisfying the requirement for discriminant validity.

\section{Structural Model}

Following the measurement model assessment, the structural model was assessed. Following Chin et al. (2008) recommendations, the structural model was tested using a bootstrapping with 5.000 iterations to evaluate the significance of the construct indicator weights as well as their path coefficients. The geometric mean of average communality and $R^{2}$ were applied to measure the model appropriateness. The results (Table 4), show that the model value is 0.454 for tourists and 0.451 for residents, suggesting the model is satisfactory.

Hair et al. (2010) state that $R^{2}$ denotes the percentage of the exogenous variable variation that is justified by the predictor(s). Table 4 shows that experience quality, perceived value, and satisfaction explain $30.6 \%(0.306)$ of the destination image variation for the tourist sample, and $24 \%$ (0.240) for the resident sample. According to Chin et al. (2008), these percentages hint that the independent variables' explanation power on destination image for both samples is moderate. $Q^{2}$ is another important indicator to review the goodness of the model. The $Q^{2}$ of experience quality, value, satisfaction, and destination image are all positive, suggesting that the prediction made by the proposed model is appropriate (Chin et al., 2008). To check the approximate fit indices, a normal fit index (NFI) and a standardized root mean square residual (SRMR) were applied. The results show that SRMR has a value of 0.078 (tourist sample) and 0.079 (resident sample), both lower than the suggested maximum value of 0.8 . NFI has a value of 0.818 (tourist sample) and 0.826 (resident sample), slightly lower than the value of 0.9 (Hair et al., 2017). Even though the NFI criteria is not satisfied, the other criteria's are acceptable, thus it can be said that the model developed is adequate.

As shown in Table 5 and Table 6 , the direct impact of experience quality on destination image and satisfaction is significant for the tourist sample $(\beta=0.258, \mathrm{p}<0.01$ and $\beta=0.321, \mathrm{p}<0.01)$, but not for the resident sample. Thus, the hypothesis $\mathrm{H}_{1}$ and $\mathrm{H}_{2}$ are supported but only for the tourist sample. As expected, experience quality has a significant direct effect on value for both tourists $(\beta=$ $0.713, \mathrm{p}<0.01)$ and residents $(\beta=0.730, \mathrm{p}<0.01)$.

Similarly, there was a positive direct effect of perceived value on satisfaction for tourists $(\beta=$ $0.252, \mathrm{p}<0.05)$ and residents $(\beta=0.375, \mathrm{p}<0.01)$. Hence, hypothesis $\mathrm{H}_{2}$ and $\mathrm{H}_{4}$ are fully supported for both samples. The influence of perceived value on destination image was found to be significant in resident sample $(\beta=0.362, \mathrm{p}<0.01)$ but not significant in the tourist sample. Thus, hypothesis $\mathrm{H}_{6}$ is supported for resident sample. Finally, the direct impact of satisfaction on destination image is 


\section{SUHARTANTO, ET AL.}

significant $(\beta=0.178, \mathrm{p}<0.01)$ for tourists but not for residents. Thus, $\mathrm{H}_{6}$ is supported for the tourist sample but not for the resident sample.

Table 5 and Table 6 also show the total effect of experience quality, value, and satisfaction (exogenous variables) on destination image (endogenous variable). These results show that the effects of all exogenous variables on destination image are significant, except for the effect of satisfaction in the resident sample. Further, the total effect report shows that the impact of experience quality on destination image is direct and also via strengthened perceived value and satisfaction. Lastly, although the influence of experience quality on destination image is significant on both samples, their degree of effect is stronger for tourists at $0.511(\mathrm{p}<0.01)$ than for residents at $0.395(\mathrm{p}<0.01)$.

Table 3. The loading, alpha, composite reliability (CR) and AVE

\begin{tabular}{|c|c|c|c|c|c|c|}
\hline & \multicolumn{3}{|c|}{ Tourist } & \multicolumn{3}{|c|}{ Resident } \\
\hline & Loading* & $\begin{array}{l}\text { Alpha } \\
\text { (CR) }\end{array}$ & AVE & Loading & $\begin{array}{c}\text { Alpha } \\
\text { (CR) }\end{array}$ & AVE \\
\hline $\begin{array}{l}\text { Experience Quality } \\
\text { (Mean: 4.110; 4.031) (Sd.: 0.521; } 0.471)\end{array}$ & & $\begin{array}{c}0.841 \\
(0.880)\end{array}$ & 0.510 & & $\begin{array}{l}0.814 \\
(0.860)\end{array}$ & 0.50 \\
\hline Escape from routine & 0.634 & & & 0.556 & & \\
\hline I like involved in the activities & 0.761 & & & 0.693 & & \\
\hline I got a unique and memorable experience & 0.727 & & & 0.721 & & \\
\hline My knowledge increase after the attraction & 0.721 & & & 0.706 & & \\
\hline I learned many new things & 0.707 & & & 0.721 & & \\
\hline During the activity, I felt relaxed & 0.752 & & & 0.728 & & \\
\hline During the activities, my privacy was assured & 0.649 & & & 0.629 & & \\
\hline $\begin{array}{l}\text { Perceived Value } \\
\text { (Mean: } 4.038 ; 4.100)(\mathrm{Sd} .: 0.559 ; 0.516)\end{array}$ & & $\begin{array}{c}0.794 \\
(0.860)\end{array}$ & 0.550 & & $\begin{array}{c}0.823 \\
(0.880)\end{array}$ & 0.59 \\
\hline Enhance personal image & 0.743 & & & 0.746 & & \\
\hline The attraction has a good 'value for money' & 0.741 & & & 0.718 & & \\
\hline The attraction fee is reasonable & 0.229 & & & 0.824 & & \\
\hline The attraction makes me accepted by others & 0.213 & & & 0.747 & & \\
\hline The attraction makes me happy & 0.316 & & & 0.715 & & \\
\hline $\begin{array}{l}\text { Satisfaction } \\
\text { (Mean: 4.391; 4.431) (Sd.: 0.526; o.524) }\end{array}$ & & $\begin{array}{c}0.691 \\
(0.870)\end{array}$ & 0.760 & & $\begin{array}{c}0.805 \\
(0.910)\end{array}$ & 0.84 \\
\hline Did not meet- meet my expectation & 0.856 & & & 0.931 & & \\
\hline Unsatisfied - Satisfied & 0.831 & & & 0.835 & & \\
\hline $\begin{array}{l}\text { Destination Image } \\
\text { (Mean: } 4.287 ; 4.335)(\mathrm{Sd} .: 0.497 ; 0.549)\end{array}$ & & $\begin{array}{l}0.737 \\
(0.870)\end{array}$ & 0.760 & & $\begin{array}{l}0.766 \\
(0.850)\end{array}$ & 0.59 \\
\hline Bandung is an interesting destination & 0.748 & & & 0.809 & & \\
\hline Bandung has a good reputation & 0.730 & & & 0.813 & & \\
\hline I like Bandung & 0.712 & & & 0.727 & & \\
\hline I intent to recommend Bandung to others & 0.776 & & & 0.685 & & \\
\hline
\end{tabular}

*significant at p<0.01, Sd.: Standard deviation; Italic: Resident sample 
Table 4. Goodness of Fit (GoF) Index

\begin{tabular}{ccccc}
\hline \multirow{2}{*}{ Variable } & \multicolumn{2}{c}{ Tourist } & \multicolumn{2}{c}{ Resident } \\
& AVE & $R^{2}$ & AVE & $R^{2}$ \\
\hline Experience quality & 0.512 & & 0.503 & \\
Perceived value & 0.549 & 0.509 & 0.587 & 0.530 \\
Satisfaction & 0.763 & 0.223 & 0.835 & 0.200 \\
Destination image & 0.558 & 0.306 & 0.589 & 0.240 \\
Average score & 0.596 & 0.346 & 0.629 & 0.323 \\
AVE $\times R^{2}$ & & 0.206 & & 0.203 \\
GoF $=\sqrt{ }\left(\mathrm{AVE} \times R^{2}\right)$ & & 0.454 & & 0.451 \\
\hline
\end{tabular}

Table 5. The result of hypotheses testing for tourist

\begin{tabular}{lcccccc}
\hline \multicolumn{1}{c}{ Path } & \multicolumn{2}{c}{ Direct effect } & \multicolumn{2}{c}{ Indirect effect } & \multicolumn{2}{c}{ Total effect } \\
& $\beta$ & t-value & $\beta$ & t-value & $\beta$ & t-value \\
\hline $\mathrm{H}_{1}$ : Experience Quality - Destination image & 0.321 & $3.543^{* *}$ & 0.190 & $2.899^{* *}$ & 0.511 & $10.137^{* *}$ \\
$\mathrm{H}_{2}$ : Experience Quality - Perceived value & 0.713 & $19.625^{* *}$ & - & - & 0.713 & $19.595^{* *}$ \\
$\mathrm{H}_{3}$ : Experience Quality - Satisfaction & 0.258 & $2.871^{* *}$ & 0.180 & $2.575^{*}$ & 0.438 & $8.633^{* *}$ \\
$\mathrm{H}_{4}$ : Perceived value - Satisfaction & 0.252 & $2.531^{*}$ & - & - & 0.252 & $2.513^{*}$ \\
$\mathrm{H}_{5}$ : Perceived value - Destination image & 0.157 & 1.754 & 0.045 & 1.748 & 0.202 & $2.239^{*}$ \\
$\mathrm{H}_{6}$ : Satisfaction - Destination image & 0.178 & $2.750^{* *}$ & - & - & 0.178 & $2.750^{* *}$ \\
\hline
\end{tabular}

**significant at $p<0.01,{ }^{*}$ significant at $p<0.05$

Table 6 . The result of hypotheses testing for resident

\begin{tabular}{llllllll}
\hline \multirow{2}{*}{ Path } & \multicolumn{3}{c}{ Direct effect } & \multicolumn{2}{c}{ Indirect effect } & \multicolumn{2}{c}{ Total effect } \\
& $\beta$ & t-value & $\beta$ & t-value & $\beta$ & t-value \\
\hline $\mathrm{H}_{1}$ : Experience Quality - Destination image & 0.093 & 0.714 & 0.300 & $3.087^{* *}$ & 0.395 & $5.134^{* *}$ \\
$\mathrm{H}_{2}$ : Experience Quality - Perceived value & 0.730 & $19.533^{* *}$ & - & - & 0.730 & $19.513^{* *}$ \\
$\mathrm{H}_{3}$ : Experience Quality - Satisfaction & 0.095 & 0.751 & 0.270 & $2.803^{* *}$ & 0.369 & $4.962^{* *}$ \\
$\mathrm{H}_{4}$ : Perceived value - Satisfaction & 0.375 & $2.992^{* *}$ & - & - & 0.375 & $2.992^{* *}$ \\
$\mathrm{H}_{5}$ : Perceived value - Destination image & 0.362 & $3.038^{* *}$ & 0.040 & 0.860 & 0.401 & $3.316^{* *}$ \\
$\mathrm{H}_{6}$ : Satisfaction - Destination image & 0.104 & 1.057 & - & - & 0.104 & 1.027 \\
\hline
\end{tabular}

${ }^{* *}$ significant at $p<0.01,{ }^{*}$ significant at $p<0.05$

\section{DISCUSSION}

First, this study demonstrates that the experience quality-destination model is a fit for both tourists and residents. This study has successfully confirmed a complex association between experience quality and destination image in creative tourism. More specifically, this study shows that for tourists and residents alike, perceived experience quality not only directly affects destination image but also indirectly affects destination image through strengthening perceived value and satisfaction. This result is consistent with Beerli and Martín (2004)'s model of destination image, which concludes that tourist vacation experience is an essential component of tourist-perceived destination image. 
This study also extends the current comprehension on the experience-image relationship (Kim et al., 2012) by revealing that the relationship between these constructs is not simple nor forward. The proposed model extends our understanding of the process of how experience quality influences destination image both for tourists and residents. This finding is important, as creative attractions are having a growing strategic role in attracting both tourists and residents while increasing the competitiveness of the destination.

Second, this study's findings expand our theoretical understanding of the link between experience quality and destination image in creative tourism. This finding suggests that the development of destination image in creative tourism should consider experience quality in their model. The mechanism underlying the complex associations among experience quality and destination image has hardly been fully explored, but this study has taken the first important steps in explaining the importance of experience quality in determining destination image, and provides some supportive evidence on Spillover Theory in creative tourism. Moreover, this finding signifies that experience quality has a large role to play in determining creative tourism destination image. This alone justifies the efforts taken to acknowledge experience quality with the creative attraction as a means to improve not only destination image, but also customer perceived value and satisfaction towards creative attraction. It is hoped that researchers will continue to use experience quality as a determinant when further developing the conceptual framework of destination image in creative tourism.

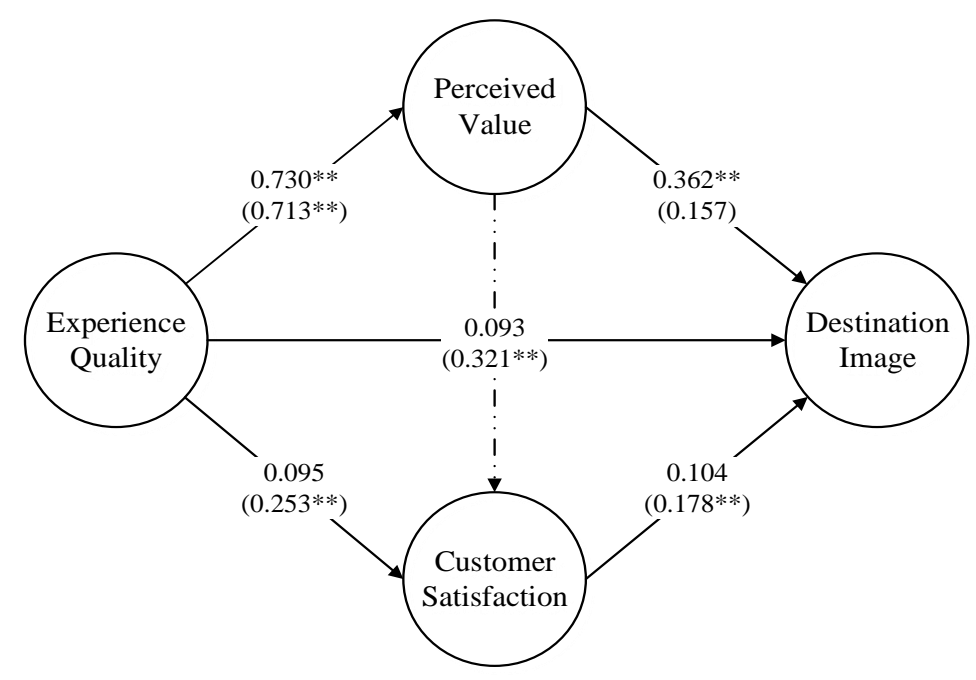

Figure 2. Summarised result

Third, although the total effect (both direct and indirect) of experience quality shows that it is an important determinant of destination image in both samples, the degree of its impact is different. The influence of experience quality on tourist sample is greater compared to that of the resident sample. This finding suggests that tourist experience with the attraction has a bigger impact on their image of the destination compared to that of the resident. The possible explanation of this finding is that image is influenced by many factors, such as experience with the service and product as well as 
the marketing communications. Past studies (Kim et al., 2012) report that the customer experience with the service is the pivotal factor in determining a person' image. As tourists' purpose of visiting the destination is to enjoy the attractions; thus, their experience with the attraction is likely to have the biggest impact on their image of the destination. In contrast, residents who work and live in the destination are constantly immersed in the destination. Thus, their experience with the attraction is only a fraction of their overall experience with the destination, which subsequently has limited effect on their image of the destination. As a consequence, the satisfaction with the attraction will significantly impact tourists' but not necessarily residents' perception on the destination image.

Lastly, while past studies (Agapito et al., 2010; Ryan \& Cave, 2005; Stylidis et al., 2017) report the differences between tourists and residents' perception on the destination image, this study extends our knowledge by identifying the similarity and difference in experience quality and destination image of tourist and residents in the creative tourism context. This study identifies important similarities between the groups of enjoying the attraction as the way to escape from daily routines and learning something new. However, this study also highlights the differences in how tourists and residents attraction experience influences their perception of the destination. Tourists' experience and satisfaction with the attractions is an important factor in determining their image of the destination, but not for residents. This partial sharing of attitudes between tourists and residents in creative activities raises questions regarding general findings that indicate residents and tourists hold distinct beliefs and attitudes towards the product or service they purchased, and these result in different behaviors (Lloyd et al., 2011; Ryan \& Cave, 2005).

\section{MANAGERIAL IMPLICATION}

This study offers a useful guidance for creative attraction managers to increase their attraction business. This study reveals that to make residents and tourists satisfied, attraction managers have to deliver a high experience quality attraction. More specifically, they need to design their attraction to fulfill the visitor's need of escapism, recognition, involvement, peace of mind, and learning. To satisfy the visitor's need of escapism and peace of mind, the managers should create the attraction to help the visitors relax and indulge themselves in the activities and offers safe attraction environment. Further, managers should ensure that visitors have the opportunity to learn something new and unique from the experience. To enable delivering these needs, having friendly and knowledgeable staff who competently provide personal care and service for the visitors is imperative.

This study suggests a path for destination managers and government agencies to follow and develop the image of their destinations. Although it is difficult to control all factors influencing image, it is possible to influence the destination image through promoting the destination with creative attractions. The promotion strategy to attract tourists visiting the destination should include creating regular special events to appeal to tourists and residents alike. While this research focused on creative tourism attractions, other tourism attractions in the destination may also positively affect the destination's image. Thus, fostering the development and encouraging the offering of creative and other tourism attractions is an important factor to develop the image of a tourism destination. 


\section{LIMITATION AND FUTURE RESEARCH}

While this study provides some important findings, it does have limitations. First, the data for this study was gathered from several creative attractions located in Bandung, Indonesia which may limit the finding's generality. It is unlikely that the effect of creative tourism on destination image is a local or regional phenomenon, but the issue can be settled with replication of this study in other destinations, especially those with a different culture. Replication studies can also focus on differentiating tourists, such as domestic and international tourists. Second, besides experience quality, satisfaction, and value that were found to directly impact destination image, it is also critical to identify other elements influencing the experience quality-destination image model. To establish a more comprehensive model, a future study might include other constructs beyond the four variables used in this study such as past experience, promotion, motivation, and socio-demographic factors which have a potential effect on experience quality and destination image.

\section{REFERENCES}

Agapito, D., Mendes, J., \& Valle, P. O. d. (2010). Destination image: perspectives of tourists vs. residents. Tourism Development and Management: Challenges and Opportunities for Algarve, Portugal, 1(1), 90-109.

Agapito, D., Oom do Valle, P., \& da Costa Mendes, J. (2013). The Cognitive-Affective-Conative Model of Destination Image: A Confirmatory Analysis. Journal of Travel \& Tourism Marketing, 30(5), 471481. doi: 10.1080/10548408.2013.803393

Ali, F., Ryu, K., \& Hussain, k. (2016). Influence of Experiences on Memories, Satisfaction and Behavioral Intentions: A Study of Creative Tourism. Journal of Travel \& Tourism Marketing, 33(1), 85-100. doi: 10.1080/10548408.2015.1038418

Beerli, A., \& Martín, J. D. (2004). Factors influencing destination image. Annals of Tourism Research, 31(3), 657-681. doi: 10.1016/j.annals.2004.01.010

Chang, L.-L., Backman, K. F., \& Huang, Y.-C. (2014). Creative tourism: a preliminary examination of creative tourists' motivation, experience, perceived value and revisit intention. International Journal of Culture, Tourism and Hospitality Research, 8(4), 401 - 419. doi: 10.1108/IJCTHR-042014-0032

Chen, C.-F., \& Chen, F.-S. (2010). Experience quality, perceived value, satisfaction and behavioral intentions for heritage tourists. Tourism Management, 31(1), 29-35. doi: 10.1016/j.tourman.2009.02.008

Chen, C.-F., \& Tsai, D. (2007). How destination image and evaluative factors affect behavioral intentions? Tourism Management, 28(4), 1115-1122. doi: 10.1016/j.tourman.2006.07.007

Chin, W. W., Peterson, R. A., \& Brown, S. P. (2008). Structural Equation Modeling in Marketing: Some Practical Reminders. Journal of Marketing Theory and Practice, 16(4), 287-298.

Choi, J. G., Tkachenko, T., Sil, S., \& Cohen, J. S. p. a. f. t. b. (2011). On the destination image of Korea by Russian tourists. Tourism Management,, 32(1), 193-194.

Deshwal, P. (2016). Customer experience quality and demographic variables (age, gender, education level, and family income) in retail stores. International Journal of Retail \& Distribution Management, 44(9), 940-955. doi: 10.1108/IJRDM-03-2016-0031 
Dodds, R., \& Jolliffe, L. (2016). Experiential Tourism: Creating and Marketing Tourism Attraction Experiences. In M. Sotiriadis \& D. Gursoy (Eds.), The Handbook of Managing and Marketing Tourism Experiences (pp. 113-129). Bingley, UK: EmeraldInsight.

García-Fernández, J., Gálvez-Ruíz, P., Fernández-Gavira, J., Vélez-Colón, L., Pitts, B., \& Bernal-García, A. (2018). The effects of service convenience and perceived quality on perceived value, satisfaction and loyalty in low-cost fitness centers. Sport Management Review, 21(3), 250-262. doi: 10.1016/j.smr.2017.07.003

Hair, J. E., Hult, G. T., Ringle, C. M., \& Sarstedt, M. (2017). A Primer on Partial Least Squares Structural Equation Modeling (PLS-SEM) (2 ed.). Thousand Oaks: Sage.

Hair, J. F., Black, W. C., Babin, B. J., \& Anderson, R. E. (2010). Multivariate data analysis: A global perspective (7th ed.). Upper Saddle River: Pearson Education.

Henseler, J., Ringle, C. M., \& Sarstedt, M. (2015). A new criterion for assessing discriminant validity in variance-based structural equation modeling. Journal of the Academy of Marketing Science, 43(1), 115-135. doi: 10.1007/s11747-014-0403-8

Hung, W.-L., Lee, Y.-J., \& Huang, P.-H. (2016). Creative experiences, memorability and revisit intention in creative tourism. Current Issues in Tourism, 19(8), 763-770. doi: 10.1080/13683500.2013.877422

Kim, H. S., \& Choi, B. (2016). The effects of three customer-to-customer interaction quality types on customer experience quality and citizenship behavior in mass service settings. Journal of Services Marketing, 3o(4), 384-397. doi:10.1108/JSM-06-2014-0194

Kim, K., Hallab, Z., \& Kim, J. N. (2012). The Moderating Effect of Travel Experience in a Destination on the Relationship Between the Destination Image and the Intention to Revisit. Journal of Hospitality Marketing \& Management, 21(5), 486-505. doi: 10.1080/19368623.2012.626745

Klaus, P. (2013). The case of Amazon.com: towards a conceptual framework of online customer service experience (OCSE) using the emerging consensus technique (ECT). Journal of Services Marketing, 27(6), 443-457. doi:10.1108/JSM-02-2012-0030

Li, M., Cai, L. A., Lehto, X. Y., \& Huang, J. (2010). A Missing Link in Understanding Revisit IntentionThe Role of Motivation and Image. Journal of Travel \& Tourism Marketing, 27(4), 335-348. doi: 10.1080/10548408.2010.481559

Lin, C.-H., Morais, D. B., Kerstetter, D. L., \& Hou, J.-S. (2007). Examining the role of cognitive and affective image in predicting choice across natural, developed, and theme-park destinations. Journal of Travel Research, 46(2), 183-194.

Lloyd, A. E., Yip, L. S. C., \& Luk, S. T. K. (2011). An examination of the differences in retail service evaluation between domestic and tourist shoppers in Hong Kong. Tourism Management, 32(3), 520-533. doi: 10.1016/j.tourman.2010.04.004

Loi, L. T. I., So, A. S. I., Lo, I. S., \& Fong, L. H. N. (2017). Does the quality of tourist shuttles influence revisit intention through destination image and satisfaction? The case of Macao. Journal of Hospitality and Tourism Management, 32, 115-123. doi: https://doi.org/10.1016/j.jhtm.2017.06.002

McLean, G., \& Wilson, A. (2016). Evolving the online customer experience ... is there a role for online customer support? Computers in Human Behavior, 6o, 6o2-610. doi: 10.1016/j.chb.2016.02.084

Meyer, C., \& Schwager, A. (2007). Understanding customer experience. Harvard Business Review, 85(2), 116-126.

Pine, B. J., \& Gilmore, J. H. (1998). Welcome to the experience economy. Harvard Business Review(JulyAugust), 97-105.

Qu, H. L., Kim, L. H., \& Im, H. H. (2011). A model of destination branding: integrating the concepts of the branding and destination image. Tourism Management, 32(3), 465-476. 


\section{SUHARTANTO, ET AL.}

Rollero, C., \& De Piccoli, N. (2010). Place attachment, identification and environment perception: An empirical study. Journal of Environmental Psychology, 30(2), 198-205. doi: 10.1016/j.jenvp.2009.12.003

Ryan, C., \& Cave, J. (2005). Structuring Destination Image: A Qualitative Approach. Journal of Travel Research, 44(2), 143-150. doi: 10.1177/0047287505278991

Sirgy, M. J., Efraty, D., Siegel, P., \& Lee, D.-J. (2001). A New Measure of Quality of Work Life (QWL) Based on Need Satisfaction and Spillover Theories. Social Indicators Research, 55(3), doi: 10.1023/A:1010986923468

Stylidis, D., Shani, A., \& Belhassen, Y. (2017). Testing an integrated destination image model across residents and tourists. Tourism Management, 58, 184-195. doi: 10.1016/j.tourman.2016.10.014

Stylos, N., Vassiliadis, C. A., Bellou, V., \& Andronikidis, A. (2016). Destination images, holistic images and personal normative beliefs: Predictors of intention to revisit a destination. Tourism Management, 53, 40-6o. doi: 10.1016/j.tourman.2015.09.006

Suhartanto, D. (2017). The role of store coopetition and attractiveness on the performance of tourism destination and its retail stores. International Journal of Tourism Policy, 7(2), 151-165. doi: 10.1504/IJTP.2017.10006051

Suhartanto, D., \& Noor, A. (2012). Customer Satisfaction in the Airline Industry: The Role of Service Quality and Price. Paper presented at the Asia Tourism Forum.

Whang, H., Yong, S., \& Ko, E. (2016). Pop culture, destination images, and visit intentions: Theory and research on travel motivations of Chinese and Russian tourists. Journal of Business Research, 69(2), 631-641. doi: 10.1016/j.jbusres.2015.06.020

Woodside, A. G., \& Dubelaar, C. (2002). A General Theory of Tourism Consumption Systems: A Conceptual Framework and an Empirical Exploration. Journal of Travel Research, 41, 120-132. doi: $10.1177 / 004728702237412$

Xu, J., \& Chan, A. (2010). Service Experience and Package Tours. Asia Pacific Journal of Tourism Research, 15(2), 177-194. doi: 10.1080/10941661003629987

Yuksel, A., Yuksel, F., \& Bilim, Y. (2010). Destination attachment: Effects on customer satisfaction and cognitive, affective and conative loyalty. Tourism Management, 31(2), 274-284.

Zhang, H., Fu, X., Cai, L. A., \& Lu, L. (2014). Destination image and tourist loyalty: A meta-analysis. Tourism Management, 40, 213-223. doi: 10.1016/j.tourman.2013.06.0o6 